\title{
An inhaled inducible nitric oxide synthase inhibitor reduces damage of Can- dida-induced acute lung injury
}

\author{
Shuji Ohsugi ${ }^{1}$, Yoshinobu Imasaki ${ }^{1}$, Yoshizumi Takemura ${ }^{1,5}$, Kazuhiro Nagata ${ }^{1}$, Hidehiko Harada ${ }^{1}$, Ichiro \\ Yokomura ${ }^{1}$, Shigekuni Hosogi ${ }^{1}$, Tatsuya Yuba ${ }^{1}$, Naomi Nissato ${ }^{2}$, Hiroaki Miyazaki ${ }^{2}$, Hiroaki Matsubara ${ }^{3}$, \\ Shinji Fushiki and Yoshinori Marunaka, ${ }^{1,2}$ \\ ${ }^{1}$ Department of Respiratory Medicine, ${ }^{2}$ Department of Molecular Cell Physiology, ${ }^{3}$ Department of Cardiovascular Medicine, ${ }^{4}$ Depart- \\ ment of Pathology and Applied Neurobiology, Graduate School of Medical Science, Kyoto Prefectural University of Medicine, Kyoto; \\ and ${ }^{5}$ Research Center for Respiratory Cell Engeering, Doshisha University, Kyoto, Japan \\ (Received 12 December 2006; and accepted 5 February 2007)
}

\begin{abstract}
Excessive nitric oxide (NO) generated by inducible nitric oxide synthase (iNOS) aggravates acute lung injury (ALI) by producing peroxynitrite. We previously showed by immunostaining that the expression of iNOS was suppressed by inhalation of $\mathrm{N}^{\mathrm{G}}$-nitro-L-arginine methyl ester in mice with Candida-induced ALI. This study tested the hypothesis that a novel iNOS inhibitor suppresses not only iNOS expression, but also iNOS messenger RNA (mRNA) production by interrupting a positive feedback loop at the time of NO production in Candida-induced ALI. Mice were pretreated by inhalation of saline or ONO-1714, a selective iNOS inhibitor, and were given an intravenous injection of Candida albicans to induce ALI. After inhalation of $1 \mathrm{mM}$ aerosolized ONO-1714, the nitrite-nitrate concentration in bronchoalveolar lavage fluid (BALF) at $24 \mathrm{~h}$ was significantly lower than that after inhalation of saline. Tumor necrosis factor- $\alpha$ (TNF- $\alpha$ ) and interleukin-1 $\beta$ (IL-1 $\beta$ ) levels and neutrophils in BALF were decreased by inhalation of ONO-1714. Inhalation of ONO-1714 markedly suppressed nitrotyrosine production and inhibited the expression of iNOS mRNA as well as proteins in the lung. Survival was prolonged by inhalation of ONO-1714. We conclude that pretreatment with inhaled ONO-1714 suppresses the production of peroxinitrite and decreases oxidative stress associated with peroxinitrite in Candida-induced ALI.
\end{abstract}

In recent years, fungi have played an increasingly important role as pathogens in nosocomial infections, and nosocomial candidemia is associated with substantial mortality and long-term hospitalization $(11,22)$. Candidemia is the fourth most common bloodstream infection in the USA at present $(2,20)$. Increased prevalence of candidemia has been associ-

Address correspondence to: Yoshinori Marunaka, M.D., Ph.D.

Department of Molecular Cell Physiology, Graduate School of Medical Science, Kyoto Prefectural University of Medicine, Kyoto 602-8566, Japan

Tel: +81-75-251-5310, Fax: +81-75-251-0295

E-mail: marunaka@koto.kpu-m.ac.jp ated with severity of illness in hospitalized patients, the use of invasive devices or procedures, and the administration of broad-spectrum antibiotics (44). Mortality among patients with candidemia remains high, ranging between $50 \%$ and $80 \%(10,43)$.

Nitric oxide (NO) plays an important role in a variety of physiological and pathophysiological processes. Three isoforms of NO synthase (NOS), neuronal NOS (nNOS, type 1), inducible NOS (iNOS, type 2), and endothelial NOS (eNOS, type 3), have been identified. These enzymes produce NO from L-arginine. After injection of lipopolysaccharide (LPS), mice lacking iNOS show not only decreased mortality, but also increase susceptibility to bacterial infection $(17,27,29,42)$. On the other 
hand, excessive production of NO may lead to the refractory hypotension, often observed in patients with septic shock $(5,7,24,41)$.

Previous studies $(30,45,47)$ have reported that iNOS can be induced in a variety of cells, including macrophages, by various stimuli, including LPS, interleukin-1 $\beta$ (IL-1 $\beta$ ), tumor necrosis factor- $\alpha$ $(\mathrm{TNF}-\alpha)$, and interferon- $\gamma(\mathrm{IFN}-\gamma)$. Excessive NO generated by iNOS aggravates acute lung injury (ALI) by producing peroxynitrite. Non-selective inhibition of NO formation could produce side effects by inhibiting the constitutive isoforms of NOS, which are responsible for the various physiological actions of NO.

Several studies $(6,31,48)$ have shown that NOS expression is regulated by a feedback regulatory action of NO. However, it is sill unclear whether in ALI the feedback mechanism functions. Therefore, we tried to confirm how iNOS expression including mRNA expression occurs in Candida-induced ALI; i.e., we hypothesized that iNOS inhibitor suppresses not only iNOS expression, but also iNOS messenger RNA (mRNA) production by interrupting such a feedback mechanism at the time of NO production in Candida-induced ALI. We also studied how a specific iNOS inhibitor, ONO-1714, acts on Candi$d a$-induced ALI by measuring nitrotyrosine protein as an index of oxidative stress caused by peroxinitrite, as well as mRNA expression of iNOS, assessed by Western blot and reverse transcription-polymerase chain reaction (RT- PCR).

\section{MATERIALS AND METHODS}

Animals. These experiments were approved by the Institutional Animal Care and Use Committee of Kyoto Prefectural University of Medicine. Specific pathogen-free $\mathrm{BALB} / \mathrm{c}$ mice (4- to 6-week-old males; Japan SLC Co., Kyoto, Japan) were used in all experiments. All mice were housed in the animal care facility at Kyoto Prefectural University of Medicine until the end of the experiment.

Experimental design. Candida albicans (C. albicans, TIMN 1623; a gift from Teikyo University, Tokyo, Japan) was maintained at $-85^{\circ} \mathrm{C}$ in Sabouraud broth supplemented with 5\% dimethylsulfoxide, and was transferred to Sabouraud dextrose agar (Eiken Chemical, Tokyo, Japan) at $37^{\circ} \mathrm{C}$ before use. Yeastphase blastospores for infusion were suspended in sterile saline solution, sedimented $(400 \mathrm{~g}, 10 \mathrm{~min}$, $4^{\circ} \mathrm{C}$ ), and resuspended in sterile saline to $5 \times 10^{7}$ cells/mL. ONO-1714, (1S,5S,6R,7R)-7-chloro-3-imi- no-5-methyl-2-azabiocyclo [4.1.0] heptane hydrochloride, was provided by ONO Pharmaceutical Co., Ltd. (Osaka, Japan), and was solubilized with physiological saline immediately before use. We developed a model of Candida-induced ALI. Mice received aerosolized saline (non-treatment group) or various concentrations $\left(10^{-3}, 10^{-2}, 10^{-1}, 1\right.$, or $\left.10 \mathrm{mM}\right)$ of ONO-1714 (ONO-1714 inhalation group) for $2 \mathrm{~h}$, followed by an injection of $1 \times 10^{7} \mathrm{C}$. albicans cells. The control group was exposed to aerosolized saline for $2 \mathrm{~h}$ and then given an injection of $0.2 \mathrm{~mL}$ saline.

Analysis of bronchoalveolar lavage fluid (BALF) and immunohistochemistry. The trachea was exposed and intubated with a 27-gauge needle after anesthetization (pentobarbital, $60 \mathrm{mg} / \mathrm{kg}$ intraperitoneal). BAL was performed by administration of $0.5 \mathrm{~mL}$ sterile saline solution three times, and the count of total cell in BALF was determined with a hemocytometer. Fluid recovery was routinely $90 \%$. Differential cell counts were performed with the use of cytospin preparations (Sakura, Tokyo, Japan) stained with Giemsa-type stain (Giff-Quick; American Scientific, McGaw Park, IL). The BALF was immediately centrifuged at $500 \mathrm{~g}$ at $4^{\circ} \mathrm{C}$ for $10 \mathrm{~min}$. The cell-free supernatant was stored at $-80^{\circ} \mathrm{C}$ for nitrite/ nitrate analysis. Nitrite/nitrate (NOx) were measured as followed. The BALF supernatant was thawed and mixed with methanol ( $1: 1$, volume/volume) to precipitate protein and then centrifuged at $10^{4} \mathrm{~g}$ at $4^{\circ} \mathrm{C}$ for $20 \mathrm{~min}$. The supernatant was applied to a nitrogen oxides analyzing system (ENO-11; EICOM, Kyoto, Japan). This system utilizes the high-performance liquid chromatography-Griess method, and nitrite/nitrate are measured separately. Cytokines (TNF- $\alpha$ and IL-1 $\beta$ ) were measured with the use of Quantikine $\mathrm{M}$ mouse IL-1 $\beta$, TNF-, and MIP-2 immunoassay kits (R\&D Systems, Minneapolis, $M N)$. The number of differential cells in the BALF was measured, and iNOS and nitrotyrosine were immunohistochemically examined as followed. Paraffin-embedded lung tissue was processed for immunohistochemical analysis. The section was dewaxed, dehydrated, and incubated with $10 \%$ normal goat serum to block nonspecific protein absorption. The section was then incubated with polyclonal anti-mouse iNOS antibody (diluted 1/500; Affinity Bioreagents, Golden, CO), anti-nitrotyrosine polyclonal antibody (diluted 1/100; Upstate Biotechnology, Lake Placid, NY), or nonimmune rabbit IgG at $4^{\circ} \mathrm{C}$ overnight. A Vectastain $\mathrm{ABC}$ kit (Vector Laboratories) was applied to visualize antibody binding. 
Bound antibodies were detected with biotinylated horse universal IgG secondary antibodies and the streptavidin-peroxidase complex, using diaminobenzidine tetrahydrochloride as substrate. The section was counterstained with Mayer hematoxylin.

$R T-P C R$. Total tissue RNA was isolated from snapfrozen lungs with the use of an RNeasy (R) Midi Kit (Qiagen Co., Tokyo, Japan) according to the manufacturer's protocol. Total RNA $(10 \mu \mathrm{g})$ was reverse-transcribed in one step using RT-PCR high -plus- (Toyobo Co., Osaka, Japan). The following primer sequences were used for iNOS: sense 5'-GGCTTGCCCCTGGAAGTTTCTCTTCAAA GTC-3' and anti-sense 5'-AAGGAGCCATAATACT GGTTGATG-3', with a final PCR product size of 441 base pairs (bp). The following primer sequences were used for $\beta$-actin: sense 5'-GAGAAGATGA CCCAGATCATG-3' and anti-sense 5'-GCCATCT CTTGCTCGAAGTC-3', with a final PCR product size of 350 bp (14). PCR was carried out on an iCycler (Bio-Rad Laboratories, Hercules, CA).

Western blot analysis. Aliquots of $30 \mu \mathrm{g}$ of lung homogenate protein were diluted with sample buffer. Proteins were subsequently transferred to a nitrocellulose membrane (clear blot membrane-P, AE-6665; ATTO Co., Tokyo, Japan). After blocking with nonfat dry milk, the membrane was incubated with a $1: 500$ dilution of the primary antibody of anti-nitrotyrosine (MON 9029; SANBIO BV, Uden, Netherlands). The membrane was subsequently incubated with a $1: 1000$ dilution of anti-mouse IgG (SC-2005; Santa Cruz Biotechnology, Inc., CA) conjugated with peroxidase. The peroxidase reaction was carried out using ECL Western blotting detection reagents.

Pulmonary fluid measurement. The lung wet-to-dry (W/D) weight ratio was determined to assess the severity of pulmonary edema as described previously (25).

Statistical analysis. All data, which are expressed as means \pm SE, were analyzed by one-way analysis of variance. Differences between groups were compared by Fisher's protected least-significant difference test; $p<0.05$ was considered to indicate statistical significance. Survival of two subgroups (non-treatment group, ONO-1714 inhalation group; $\mathrm{n}=12$ per group) was estimated by the Kaplan-Meier method, and curves were compared by log-rank tests.

\section{RESULTS}

Nitrite and nitrate levels in BALF

To determine the optimal concentration of aerosolized ONO-1714, the mice were exposed to saline or various concentrations of ONO-1714 for $2 \mathrm{~h}$ before C. albicans administration. The mice were anesthetized and euthanized before BAL. BALF NOx levels significantly increased $24 \mathrm{~h}$ after administration of $C$. albicans in the non-treatment group. The NOx levels after the induction of candidemia were inhibited by ONO-1714 in a dose-dependent manner by concentrations from $10^{-3} \mathrm{mM}$ to $1 \mathrm{mM}$. NOx levels were similar after treatment with aerosolized $1 \mathrm{mM}$ and $10 \mathrm{mM}$ ONO-1714. After pretreatment with aerosolized $1 \mathrm{mM}$ ONO-1714, the nitrite/nitrate level was significantly lower than that in the nontreatment group (Fig. 1A). We therefore selected $1 \mathrm{mM}$ aerosolized ONO-1714 (ONO-1714 inhalation group) for subsequent treatment in our study to clearly study the effect of ONO-1714 possibly without other side effects.

\section{Western blot analysis of nitrotyrosine}

As shown in Fig. 1B, the amount of nitrotyrosine protein in the lung homogenates from the non-treatment group with Candida administration was significantly higher than that in the lung homogenates from the control group. The amount of nitrotyrosine protein in the ONO-1714 inhalation group was significantly lower than that in the non-treatment group.

\section{Immunoreactivity of nitrotyrosine}

Immunohistochemical images of lung specimens labeled with polyclonal antibody to nitrotyrosine are shown in Fig. 2. In the non-treatment group, immunohistochemical staining of protein nitrotyrosine residues was observed throughout the lung. The alveolar epithelial cells were darkly stained. After ONO-1714 inhalation, the alveolar epithelial cells were lightly stained. Scant staining was observed in the lung tissue of the control group (not shown).

\section{Cytokine levels in BALF}

To examine the influence of inhaled ONO-1714 on cytokine productions, cytokine analysis was performed $24 \mathrm{~h}$ after inoculation. The IL- $1 \beta$ and TNF- $\alpha$ levels in BALF from the non-treatment group were significantly higher than the corresponding levels in the control group. The IL- $1 \beta$ and TNF- $\alpha$ levels in BALF from the ONO-1714 inhalation group were significantly lower than those in the non-treatment 


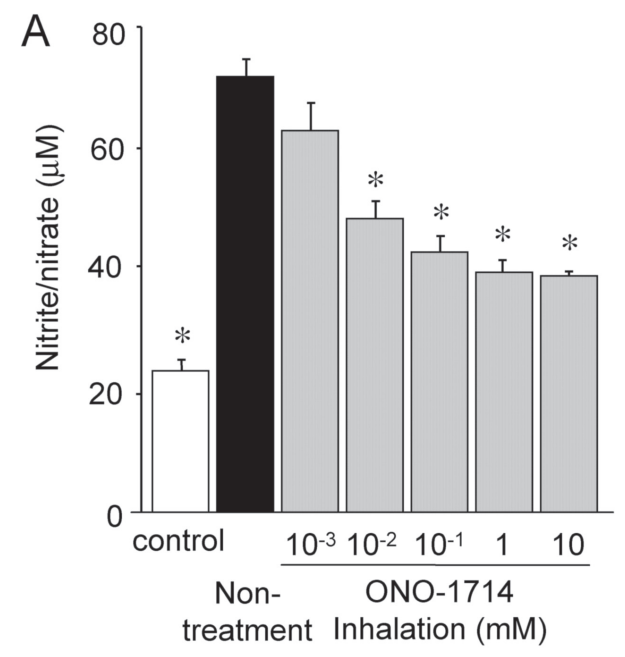

B

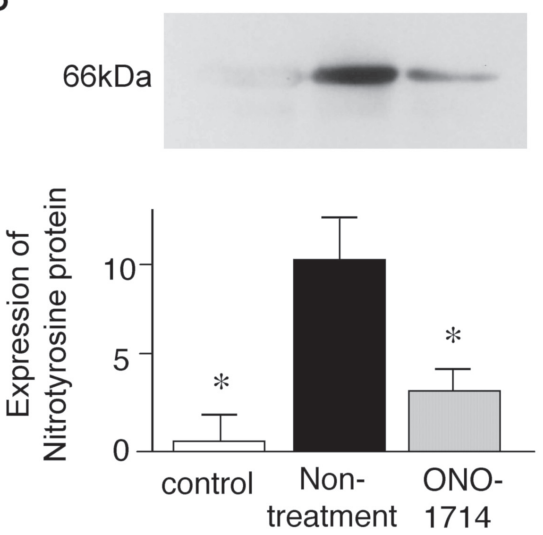

Fig. 1 A) Effect of inhaled ONO-1714 on nitrite and nitrate levels in BALF after intravenous injection of $C$. albicans. Data are means \pm SEM of 6 animals. ${ }^{*}, p<0.05$ as compared with non-treatment group. B) Nitrotyrosine protein expression in lung tissue examined by Western blotting. Data are means \pm SEM of 3 animals. ${ }^{*}, p<0.05$ as compared with non-treatment group.

group (Fig. 3A).

\section{Total cell counts and neutrophils in BALF}

To confirm the effect of inhaled ONO-1714 on neutrophil accumulation, we collected BALF $24 \mathrm{~h}$ after inoculation. The numbers of total cells and neutrophils in BALF from the non-treatment group were significantly higher than those in BALF from the control group. The numbers of total cells and neutrophils in the ONO-1714 inhalation group were significantly lower than those in the non-treatment group (Fig. 3B).

\section{RT-PCR for iNOS}

Total RNA was extracted from the lungs of mice and was then electrophoresed and hybridized with cDNA probe for iNOS. As shown in Fig. 4, the expression of mRNA in lungs was significantly lower in the ONO-1714 inhalation group than in the nontreatment group.

iNOS immunoreactivity in the lung

Paraffin-embedded sections from the non-treatment group exhibited marked immunostaining with polyclonal antibody to iNOS. Immunoreactivity for iNOS was primarily found in alveolar epithelial cells, possibly both type I and II cells but not macrophages (Fig. 5A). In the ONO-1714 inhalation group, however, immunostaining of iNOS was markedly attenuated, and only light staining of alveolar epithelial cells was observed (Fig. 5B). No significant immunoreactivity was detected in the control group (data not shown).

\section{Lung wet-dry weight ratio}

We studied the effect of ONO-1714 inhalation on lung wet-dry ratio in ALI lungs. The lung wetdry ratio was increased by Candida injection. ONO-1714 inhalation diminished the lung wet-dry ratio from the increased level to the normal one (Fig. 6).

\section{Survival}

By day 2 after inoculation, mortality was $40 \%$ in the non-treatment group. There was no mortality up to day 3 in the ONO-1714 inhalation group. Median survival was 1.6 days in the non-treatment group and 4.7 days in the ONO-1714 inhalation group. This difference was statistically significant $(\mathrm{p}<0.001$ by the log-rank test; $n=10$ ). We could not determine the causes of death in our study, but survival was improved by treatment with inhaled ONO-1714 in mice with lethal candidemia.

\section{DISCUSSION}

Induction of iNOS is a much greater stimulus of $\mathrm{NO}$ production than activation of nNOS and eNOS. In physiologic states, NO may scavenge superoxide to protect lung tissues, but excessive production of NO may produce tissue damage caused by NO reacting with superoxide to form peroxinitrite, a strong oxidant $(3,19,21)$. Peroxynitrite is considered an important oxidant in various diseases (35). In the present study, pretreatment with $1 \mu \mathrm{M}$ to $1 \mathrm{mM}$ aerosolized ONO-1714, dose-dependently diminished nitrite/nitrate levels in BALF.

We examined the expression of nitrotyrosine in 

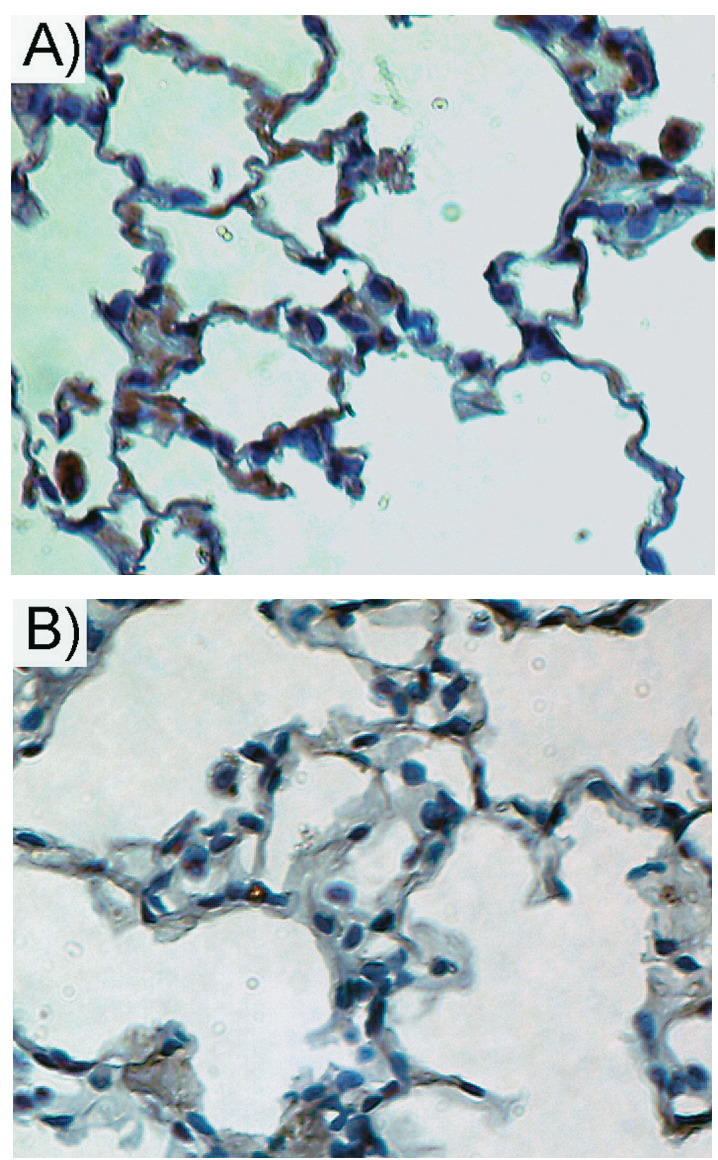

Fig. 2 Immunostaining of lung tissue for anti-nitrotyrosine $24 \mathrm{~h}$ after inoculation ( $\mathrm{n}=3$ per group). A) Non-treatment group: marked immunostaining of iNOS in alveolar epithelial cells. B) ONO-1714 inhalation group: weak staining of alveolar epithelial cells. Original magnification: $\times 400$.

the lung by means of immunohistochemical staining and Western blotting to evaluate the oxidative stress caused by peroxinitrite derived from superfluous nitric oxide and superoxide in the lung. Our results showed that the production of nitrotyrosine in the lung was significantly suppressed by the inhalation of ONO-1714. Inhalation of ONO-1714 also significantly reduced the expression of iNOS and nitrotyrosine considered markers of peroxynitrite tissue damage, in alveolar epithelial cells. Among the many organs previously studied, the lungs express the highest iNOS activity in response to endotoxin injection in the rat (40). This finding suggests that the local administration of an iNOS inhibitor to the lung may be effective for the treatment of ALI.

Proinflammatory cytokines, such as IL- $1 \beta$ and TNF- $\alpha$, have been implicated in endotoxin shock (4, $8,16,33)$. Intravenous administration of these cytokines induces pulmonary edema and death, similar
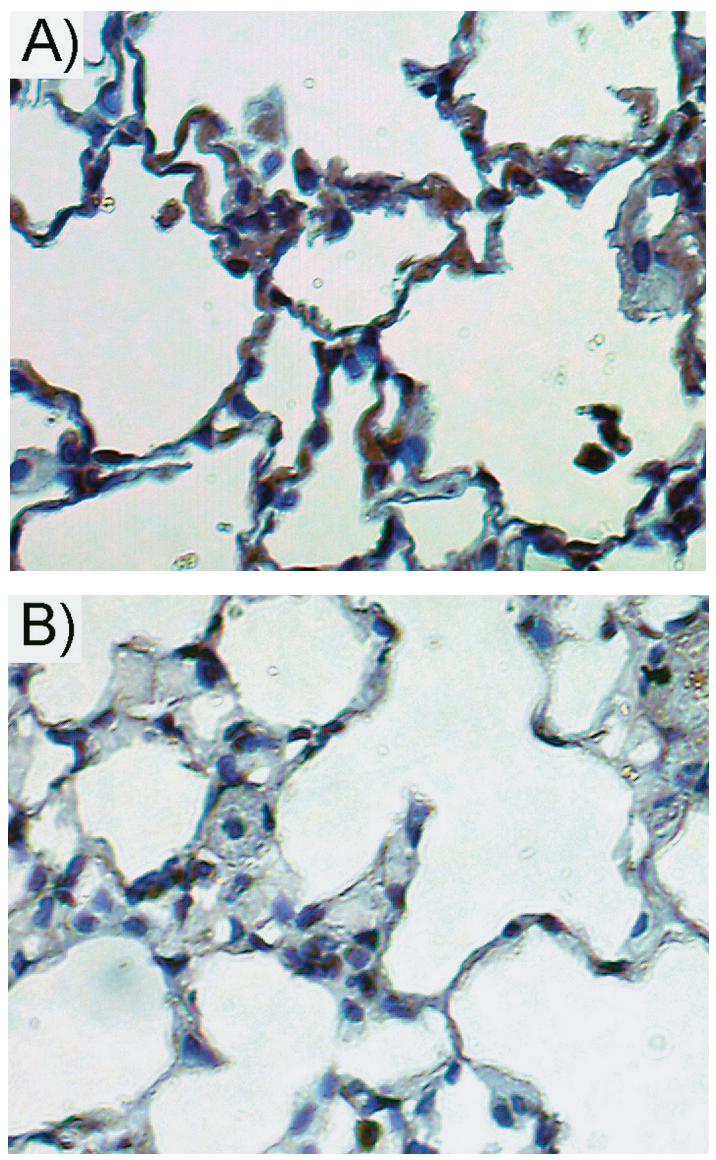

Fig. 5 Immunostaining of lung tissue for iNOS $24 \mathrm{~h}$ after inoculation ( $n=3$ per group). A) Non-treatment group: marked immunostaining of iNOS in alveolar epithelial cells. B) ONO-1714 inhalation group: weak staining of alveolar epithelial cells. Original magnification: $\times 400$.

to the septic shock syndrome $(8,38)$. iNOS can be expressed after exposure to endotoxin and cytokines in macrophages, neutrophils, mast cells, endothelial cells, and vascular smooth muscle cells $(12,17,39)$. As for the random migration of neutrophils to the lung, macrophage inflammatory protein (MIP-2) has been shown to be a powerful neutrophil migration factor in rodents (15). Greenberger et al. (13) have reported that administration of anti-MIP-2 antibody prevents neutrophils from integration to the lung in a model of Klebsiella pneumonia. This effect was accompanied by decreased capability to remove Klebsiella from the lung (13). In the lungs, alveolar macrophages and airway epithelial cells are the main cells in which cytokines induce iNOS expression and NO formation (18). Kubota et al. (25) demonstrated that survival was prolonged despite decreased clearance of Candida from the lungs in alveolar macrophage-depleted mice as compared 
A

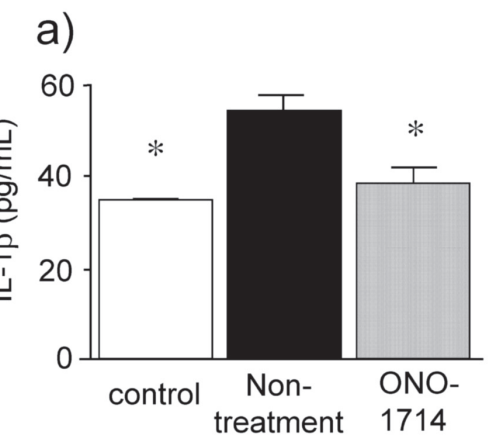

B

a)

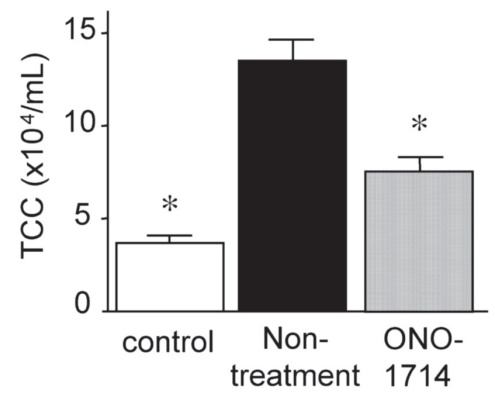

b)

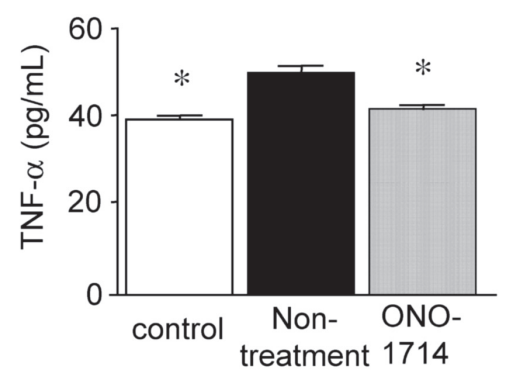

b)

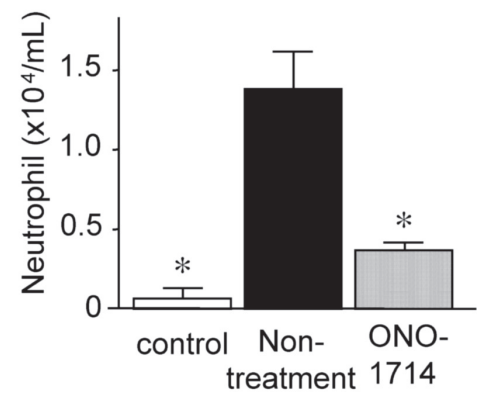

Fig. 3 A) Effect of inhaled ONO-1714 on BALF IL-1 $\beta$ (a) and TNF- $a$ (b) levels after intravenous injection of $C$. albicans. B) Effect of inhaled ONO-1714 on total cell counts (TTC) (a) and neutrophils (b) in BALF after intravenous injection of $C$. albicans. Data are means \pm SEM of 6 animals. ${ }^{*}, p<0.05$ as compared with non-treatment group.

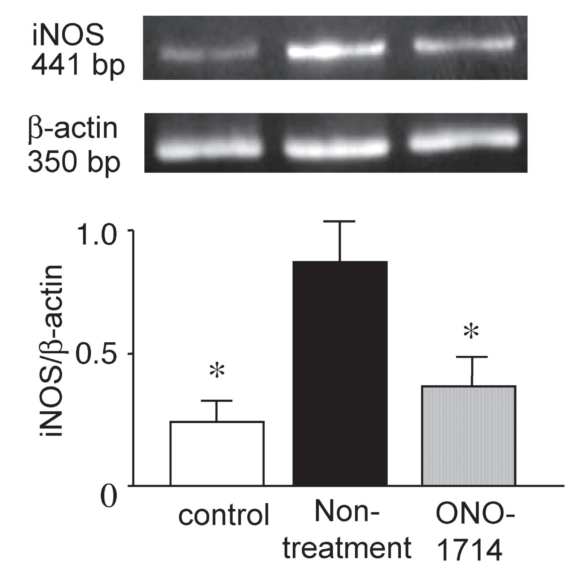

Fig. 4 iNOS mRNA expression in the lung tissue as assessed by reverse transcription polymerase chain reaction (RT-PCR). Data are means \pm SEM of 3 animals. ${ }^{*}, p<0.05$ as compared with non-treatment group.

with alveolar macrophage-sufficient mice. In this study, we demonstrated that total cell and neutrophil counts in BALF were significantly decreased by in-

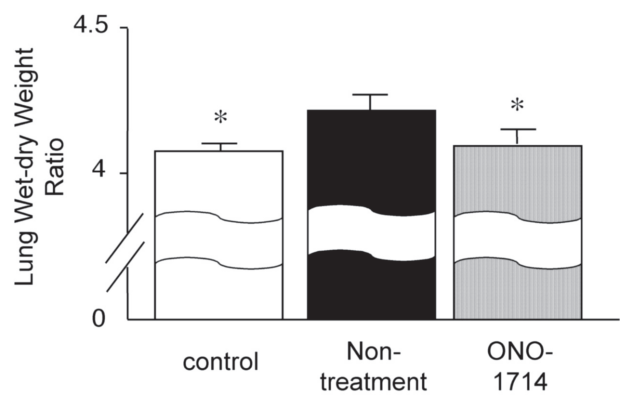

Fig. 6 Effect of inhaled ONO-1714 on lung W/D weight ratios after intravenous injection of $C$. albicans. Data are means \pm SEM of 6 animals. ${ }^{*}, p<0.05$ as compared with non-treatment group.

halation of ONO-1714. The random migration of inflammatory cells (mainly neutrophils to the lung) was also suppressed.

To our knowledge, the present study reports here for the first time to show that inhalation of ONO-1714 as a pretreatment suppresses the expression of iNOS in the lung not only at the protein lev- 
el, but also at the mRNA level in Candida-induced ALI. Consequently, the lung W/D weight ratio was significantly lower and survival was significantly longer in the ONO-1714 inhalation group than in the non-treatment group. The present study demonstrated that inhalation of ONO-1714 reduced the tissue injury caused by peroxynitrite and suppressed the production of iNOS locally in the lung. Our results for the W/D ratio conflict with the finding of Okamoto et al. (37) who have reported that ONO-1714 did not reduce the W/D ratio. However, other studies have shown a significant increase in the lung W/D ratio when yeast-form Candida of $10^{7}$ was injected into mice intravenously $(1,26,32)$. Our results agree with those of a study by Kristof et al. (23), using mice lacking the iNOS gene.

Nuclear factor- $\kappa \mathrm{B}(\mathrm{NF}-\mathrm{\kappa} \mathrm{B})$ is a member of a family of transcriptional factors first described in $\mathrm{B}$ lymphocytes that regulate transcription of iNOS. Two nitric oxide-mediated effects on the NF- $\mathrm{kB}$ activation pathway have been reported, a stimulatory effect and an inhibitory effect. Murine iNOS promoter contains 24 transcriptional factor binding sites, including those for NF- $\mathrm{KB}$ and activator protein-1 $(28,47)$. Proteins of the NF- $\mathrm{KB}$ family appear to be essential for the enhanced iNOS gene expression seen in macrophages exposed to LPS (46), and p65 NF- $\mathrm{kB}$ is considered responsible for iNOS induction in astrocytes (9). Marcinkiewicz et al. (31) have reported that excessive production of NO could activate a positive feedback loop, leading to increased release of a variety of macrophage inflammatory mediators, such as IL- $1 \alpha$ and TNF- $\alpha$. Their findings suggest an important self-amplifying mechanism, since iNOS is under NF- $\kappa \mathrm{B}$ control. Our findings that ONO-1714 significantly attenuated the expression of iNOS mRNA in the lung indicated that ONO-1714 may interrupt such a positive feedback.

ONO-1714 is 451-fold more potent than NGmonomethyl-L-arginine monoacetate (L-NMMA) in terms of inhibiting human iNOS, and ONO-1714 is 10-fold more selective for human iNOS than for human nNOS or eNOS. In fact, ONO-1714 is about 34-fold more selective for human iNOS than L-NMMA (36). One study has reported that treatment with ONO-1714 $12 \mathrm{~h}$ after cecal ligation and puncture significantly reduces NOx levels in plasma and improves survival (37). Another study has shown that two types of treatments, pre-treatment and early post-treatment with ONO-1714 (within $2 \mathrm{~h}$ after the infusion of endotoxin) improve ALI (34), although the precise mechanism involved remains unknown.
ONO-1714 is unable to directly inhibit inflammatory mediators (e.g., $\mathrm{O}_{2}{ }^{-}$) other than NO. Thus, the prophylactic or therapeutic effectiveness of using an iNOS inhibitor in Candida-induced ALI may be limited. A better response may be achieved by combining ONO-1714 with drugs that suppress other toxic inflammatory mediators. Although inhaled ONO-1714 may be useful for the treatment of Candida ALI, whether the drug is effective after onset of infection or when given in multiple doses remains unclear.

In conclusion, pretreatment with inhaled ONO1714, a new inducible nitric oxide synthase inhibitor, suppressed the production of peroxinitrite and decreased the oxidative stress caused by peroxinitrite in Candida-induced ALI. The iNOS inhibitory effect of ONO-1714 was seen at both protein and mRNA levels.

\section{Acknowledgements}

We thank ONO Pharmaceutical Co., Ltd. (Osaka, Japan) for providing ONO-1714. This work was supported by Grants-in-Aid from Japan Society of The Promotion of Science (18590861, 18659056, 17390057, 17590191)

\section{REFERENCES}

1. Allendoerfer R, Magee DM, Smith JG, Bonewald L and Graybill JR (1993) Induction of tumor necrosis factor- $\alpha$ in murine Candida albicans infection. J Inf Dis 167, 1168-1172.

2. Banerjee SN, Emori TG, Culver DH, Gaynes RP, Jarvis WR, Horan T, Edwards JR, Tolson J, Henderson T and Martone WJ (1991) Secular trends in nosocomial primary bloodstream infections in the United States. 1980-1989. National Nosocomial Infections Surveillance System. Am J Med 91 (Supp1 3B), 86-89.

3. Beckman JS, Ischiropoulos $\mathrm{H}$, Zhu $\mathrm{L}$, van der Woerd M, Smith C, Chen J, Harrison J, Martin JC and Tsai M (1992) Kinetics of superoxide dismutase and iron catalyzed nitration of phenolics by peroxynitrite. Arch Biochem Biophys 298, 438-445.

4. Brigham KL and Meyrick B (1983) Endotoxin and lung injury. Am Review Respir Dis 133, 913-927.

5. Booke M, Hinder F, Traber LD, McGuire R and Traber DL (1995) S-Ethylisothiourea, a nonamino acid inhibitor of nitric oxide synthase, reverses septic vaodilation in sheep. Shock $\mathbf{4}$, 274-281.

6. Chen JX, Berry LC, Tanner M, Chang M, Myers RP and Meyrick B (2001) Nitric oxide donors regulate nitric oxide synthase in bovine pulmonary artery endothelium. $J$ Cell Physiol 186, 116-123.

7. Di Massimo C, Scarpelli P, Di Lorenzo N, Caimi G, di Orio F and Ciancarelli MG (2006) Impaired plasma nitric oxide availability and extracellular superoxide dismutase activity in healthy humans with advancing age. Life Sci 78, 1163-1167.

8. Dinarello CA and Wolff SM (1993) The role of interleukin-1 
in disease. New Engl J Med 328,106-113.

9. Feinstein DL, Galea E, Aquino DA, Li GC, Xu H and Reis DJ (1996) Heat shock protein 70 suppresses astroglial-inducible nitric-oxide synthase expression by decreasing NFkB activation. J Biol Chem 27, 17724-17732.

10. Fraser VJ, Jones M, Dunkel J, Storfer S, Medoff G and Dunagan WC (1992) Candidemia in a tertiary care hospital: epidemiology, risk factors and predictors of mortality. Clin Inf Dis 15, 414-421.

11. Fridkin SK and Jarvis WR (1996) Epidemiology of nosocomial fungal infections. Clin Microbiol Rev 9, 499-511.

12. Geller DA, Nussler AK, Di Silvio M, Lowenstein CJ, Shapiro RA, Wang SC, Simmons RL and Billiar TR (1993) Cytokine, endotoxin, and glucocorticoides regulate the expression of inducible nitric oxide synthase in hepatocytes. Proc Natl Acad Sci USA 90, 522-526.

13. Greenberger MJ, Strieter RM, Kunkel SL, Danforth JM, Laichalk LL, McGillicuddy DC, and Standiford TJ (1996) Neutralization of macrophage inflammatory protein-2 attenuates neutrophil recruitment and bacterial clearance in murine Klebsiella pneumonia. J Inf Dis 173, 159-165.

14. Gunnett CA, Heistad DD, Loihl A and Faraci FM (2000) Tumor necrosis factor-alpha impairs contraction but not relaxation in carotid arteries from iNOS-deficient mice. $A m J$ Physiol Reg Integ Comp Physiol 279, R1558-R1564.

15. Gupta S, Feng L, Yoshimura T, Redick J, Fu SM and Rose Jr CE (1996) Intra-alveolar macrophage-inflammatory peptide 2 induces rapid neutrophil localization in the lung. $\mathrm{Am} \mathrm{J}$ Respir Cell Mol Biol 15, 656-663.

16. Hamid Q, Springall DR, Riveros-Moreno V, Chanez P, Howarth $\mathrm{P}$, Redington A, Bousquet J, Godard P, Holgate S and Polak JM (1993) Induction of nitric oxide synthase in asthma. Lancet 342, 1510-1513.

17. Hashimoto M, Ito T, Fukumitsu H, Nomoto H, Furukawa $\mathrm{Y}$ and Furukawa S (2005) Stimulation of production of glial cell line-derived neurotrophic factor and nitric oxide by lipopolysaccharide with different dose-responsiveness in cultured rat macrophages. Biomed Res 26, 223-229.

18. Heiss LN, Lancaster Jr JR, Corbett JA and Goldman WE (1994) Epithelial autotoxicity of nitric oxide: role in the respiratory cytopathology of pertussis. Proc Natl Acad Sci USA 91, 267-270.

19. Ischiropoulos H, Zhu L and Beckman JS (1992) Peroxynitrite formation from macrophage-derived nitric oxide. Arch Biochem Biophys 298, 446-451.

20. Jarvis WR (1995) Epidemiology of nosocomial fungal infections, with emphasis on Candida species. Clin Inf Dis 20, $1526-1530$

21. Khanduja KL, Sohi KK, Pathak CM and Kaushik G (2006) Nimesulide inhibits lipopolysaccharide-induced production of superoxide anions and nitric oxide and iNOS expression in alveolar macrophages. Life Sci 78, 1662-1669.

22. Klein JJ and Watanakunokorn C (1979) Hospital-acquired fungemia. Its natural course and clinical significance. $\mathrm{Am} \mathrm{J}$ Med 67, 51-58.

23. Kristof AS, Goldberg P, Laubach V and Hussain SN (1998) Role of inducible nitric oxide synthase in endotoxin-induced acute lung injury. Am J Respir Crit Care Med 158, 18831889.

24. Kroncke KD, Fehsel K and Kolb-Bachofen V (1998) Inducible nitric oxide synthase in human diseases. Clin Exp Immunol 113, 147-156.

25. Kubota Y, Iwasaki Y, Harada H, Yokomura I, Ueda M, Hashimoto S and Nakagawa M (2001) Role of alveolar mac- rophages in Candida-induced acute lung injury. Clin Diag Lab Immunol 8, 1258-1262.

26. Lechner AJ, Ryerse JS and Matuschak GM (1993) Acute lung injury during bacterial or fungal sepsis. Microscopy Res Tech 26, 444-456.

27. Li W, Tsubouchi R, Qiao S, Haneda M, Murakami K and Yoshino M (2006) Inhibitory action of eugenol compounds on the production of nitric oxide in RAW264.7 macrophages. Biomed Res 27, 69-74.

28. Lowenstein CJ, Alley EW, Raval P, Snowman AM, Synder SH, Russell SW and Murphy WJ (1993) Macrophage nitric oxide synthase gene: two upstream regions mediate induction by interferon gamma and lipopolysaccharide. Proc Natl Acad Sci USA 90, 9730-9734.

29. MacMicking JD, Nathan C, Hom G, Chartrain N, Fletcher DS, Trumbauer M, Stevens K, Xie QW, Sokol K, Hutchinson N, Chen H and Mudgett JS (1995) Altered responses to bacterial infection and endotoxic shock in mice lacking inducible nitric oxide synthase. Cell 81, 641-650.

30. MacNaul KL and Hutchinson NI (1993) Differential expression of iNOS and cNOS mRNA in human vascular smooth muscle cells and endothelial cells under normal and inflammatory conditions. Biochem Biophys Res Commun 196, 1330-1334.

31. Marcinkiewicz J, Grabowska A and Chain B (1995) Nitric oxide up-regulates the release of inflammatory mediators by mouse macrophages. Eur J Immunol 25, 947-951.

32. Matuschak GM, Klein CA, Tredway TL, Schilly DR and Lechner AJ (1993) TNF- $\alpha$ and cyclooxygenase metabolites do not modulate C. albicans septic shock with disseminated candidasis. J Appl Physiol 74, 2432-2442.

33. Michie HR, Manogue KR, Spriggs DR, Revhaug A, O'Dwyer S, Dinarello CA, Cerami A, Wolff SM and Wilmore DW (1988) Detection of circulating tumor necrosis factor after endotoxin administration. New Engl J Med 318, 1481-1486.

34. Mikawa K, Nishina K, Takao Y and Obara H (2003) ONO-1714, a nitric oxide synthase inhibitor, attenuates endotoxin-induced acute lung injury in rabbits. Anesth Analg 97, $1751-1755$.

35. Mulligan MS, Hevel JM, Marletta MA and Ward PA (1991) Tissue injury caused by deposition of immune complexes is L-arginine dependent. Proc Natl Acad Sci USA 88, 63386342.

36. Naka M, Nanbu T, Kobayashi K, Kamanaka Y, Komeno M, Yanase R, Fukutomi T, Fujimura S, Seo HG, Fujiwara, N, Ohuchida S, Suzuki K, Kondo K and Taniguchi N (2000) A potent inhibitor of inducible nitric oxide synthase, ONO1714, a cyclic amidine derivative. Biochem Biophys Res Commun 270, 663-667.

37. Okamoto I, Abe M, Shibata K, Shimizu N, Sakata N, Katsuragi T and Tanaka K (2000) Evaluating the role of inducible nitric oxide synthase using a novel and selective inducible nitric oxide synthase inhibitor in septic lung injury produced by cecal ligation and puncture. Am J Respir Crit Care Med 162, 716-722.

38. Okusawa S, Gelfand JA, Ikejima T, Connolly RA and Dinarello CA (1988) Interleukin-1 induces a shock-like state in rabbits: synergism with tumor necrosis factor and the effect of cyclooxygenase inhibition. J Clin Invest 81, 1162-1172.

39. Stuehr DJ, Marletta MA (1987) Induction of nitrite/nitrate synthesis in murine macrophages by BCG infection, lymphokines or interferon- $\gamma$. J Immunol 139, 518-525.

40. Szabo C, Mitchell JA, Thiemermann C and Vane JR (1993) Nitric oxide-mediated hyporeactivity to noradrenaline pre- 
cedes the induction of nitric oxide synthase in endotoxin shock. Br J Pharmacol 108, 786-792.

41. Szabo C, Southan GJ and Thiemermann C (1994) Beneficial effects and improved survival in rodent models of septic shock with S-methylisothiourea sulfate, a potent and selective inhibitor of inducible nitric oxide synthase. Proc Natl Acad Sci USA 91 12472-12476.

42. Wei XQ, Charles IG, Smith A, Ure J, Feng GJ, Huang FP, Xu D, Muller W, Moncada S and Liew FY (1995) Altered immune responses in mice lacking inducible nitric oxide synthase. Nature 375, 408-411.

43. Wey SB, Mori M, Pfaller MA, Woolson RF and Wenzel RP (1988) Hospital acquired candidemia: the attributable mortality and excess length of stay. Arch Intl Med 148, 2642-2645.

44. Wey SB, Mori M, Pfaller MA, Woolson RF and Wenzel RP (1989) Risk factors for hospital-acquired candidemia: a matched case-control study. Arch Intl Med 149, 2349-2353.

45. Xie QW, Cho HJ, Calaycay J, Mumford RA, Swiderek KM, Lee TD, Ding A, Troso T and Nathan C (1992) Cloning and characterization of inducible nitric oxide synthase from mouse macrophages. Science 256, 225-228.

46. Xie QW, Kashiwabara Y and Nathan C (1994) Role of transcription factor NF-kappa B/Rel in induction of nitric oxide synthase. J Biol Chem 269, 4705-4708.

47. Xie QW, Whisnant R and Nathan C (1993) Promoter of the mouse gene encoding calcium-independent nitric oxide synthase confers inducibility by interferon gamma and bacterial lipopolysaccharide. J Exp Med 177, 1779-1784.

48. Yuhanna IS, MacRitchie AN, Lantin-Hermoso RL, Wells LB and Shaul PW (1999) Nitric oxide (NO) upregulates NO synthase expression in fetal intrapulmonary artery endothelial cells. Am J Respir Cell Mol Biol 21, 629-636. 
